\title{
The Birdstone and Its Probable Use
}

Among the many problematic slate forms of contemporaneous American Indian culture, probably none have been so commented upon as the birdstones. With few exceptions these are all well made, graceful, and excel any of the other slate forms in this respect. There is nothing to associate the bird form with any existing belief or custom of the American Indian of today. ${ }^{88}$

Most birdstones are found in an area embraced by the states of New York, Ohio, Indiana, Michigan and Wisconsin. They are of course found in other states, but seem to have their focal point in the states mentioned. These states, as will be observed, are all in close proximity to or bordered by the lake area, or contain extensive waterways. I make distinct note of this for it is important to the theory to be advanced.

The variety of materials from which birdstones are made seems to be restricted; banded or Huronian slate predominating over other grades or slate, sandstone and granite. They have many characteristics in common, such as the method and angle of perforation, the straight, slightly curved or saddle base, absence of file marks, development of the so-called eye, and the final finish of the completed object.

Warren K. Moorehead, in Stone Ornaments of the American Indian, divides birdstones into six classes as follows (p. 81): (a) the ordinary bird-stone; (b) the birdstone with slender body, neck and head specialized; $(c)$ birdstone with short body; $(d)$ short, wide birdstone, southern type; $(e)$ birdstone with wide body and large ears; and $(f)$ the variations of another type.

The theories advanced regarding their probable use are many, wide and variable. Henry Gilman, Smithsonian Rept., 1873, says, "they are worn on the heads of Indian women but only after marriage"; and William Penn says, "when the squaws are ready to marry they wear something on their head to indicate the fact." Some authorities have presumed that the birdstone was referred to in this case. If this were true, Penn would undoubtedly have mentioned it; certainly something as distinctive as the bird form would have been noted. The mere wearing of a head ornament to indicate the status of a person. before or after marriage is a common trait among the more primitive peoples of the world, and is practiced today. To cite a specific instance; the maidens of the Pearl Island group wear a red hibiscus blossom over the right ear when foot-loose and fancy-free, and after the marriage wear the flower over the left ear. In some European countries, certain methods of dressing the hair, or the type of headgear worn are used to indicate the marriageable status of the person in question.

Jones, in Antiquities of the Southern Indians, quotes De Bry as saying, "the Indian conjurors wore a small black bird above one of their ears as a badge of

${ }^{88}$ Editor's note: Mr. Allen's article, "Significance of the so-called Bird-Stone," this series, Vol. 1, No. 3, p. 224, was printed after the present article was received. 
office." I remark at this time that De Bry makes no mention of what this bird was or of what it was made. No doubt he was referring to a custom which was prevalent among the medicine men of some of our Indian tribes within recent times, and which entailed the removal of the entrails of a bird, the curing of its body and the wearing of it in their hair as part of the regalia of office. Lafiteau (Vol. III, p. 50) says, "On solemn occasions, as on gala days, the Iroquois wore above the ear a tuft of feathers or the whole skin of some rare bird"; while Adair (p. 81) notes the same custom among the southern Indians.

Dr. William Beauchamp, Bulletin of the New York State Museum, Vol. 14 , No. 18, 1897, says, "It seems better to class them (the birdstones) with the war and prey or hunting gods of the $Z$ uñi, some of which they resemble." There is no question as to their resemblance but here the likeness seems to cease. Among the great number of fetishes collected and commented upon by Frank H. Cushing in the Annual Report of the Bureau of American Ethnology for $1880-81$, it is well to note that among the objects illustrated and described, none of them compare in essential points with the bird forms. The birds follow distinct lines, with certain minor variations. After examining hundreds of them, it becomes evident that they were manufactured with a definite purpose in mind and adhered to certain standard patterns. This cannot be said of the Zuñi fetishes.

Another theory previously advanced, and one which this letter seeks to substantiate, is that they were used as canoe-prow ornaments. Charles E. Brown, in the Wisconsin Archeologist, Vol. 8, No. 1, presents a map showing that in Wisconsin birdstones were most numerous along the shore of Lake Michigan, using this as an argument that their distribution was influenced by trade routes. To my mind the trade-route supposition is feasible to a certain degree, but we must remember that trade routes were not confined exclusively to waterways. It is well to note that the western shore of this lake does produce many specimens of this form, and I make more then a passing note of this fact. From earliest historic times this shore has been under the control of the Winnebago, who used canoes. It is interesting to note that while the shore of Lake Michigan and the lake portion of Wisconsin have produced the birdstone in great numbers, New York and Ohio, particularly in the lake and waterway area, and Indiana, have also produced an unusual quota of the bird forms.

I believe that the development of the birdstone along with certain other ceremonial forms of polished slate, is a cultural manifestation of the Iroquoian tribes, introduced by them and accepted with certain modifications by various tribes with whom they came in contact. This theory is of course suppositional on my part, yet it is substantiated to a degree by the great number of polished slate objects found in the localities of strongest Iroquoian influence. For example, the territory lying between the Youghiogheny and Monongahela Rivers, in Pennsylvania, containing hundreds of square miles and uncounted village sites, all of archaic Algonkian occupancy, shows a negligible quantity of the bird 
forms, and very few of the problematic slate forms. When found, these objects are generally very crude, apparently copies of the better polished slate forms. These sites were evidently occupied and abandoned many years before the Iroquois had started on their wars of conquest in this territory. At that time only slight contact had been made by the Iroquois with these people. In the Allegheny River valley, where the Iroquois and Delaware had fought and driven from this territory the legendary Allegwi, the occurrence of these objects is not uncommon on sites subsequently occupied by the Iroquois.

C. C. Abbott, in Primitive Industry, p. 372, says, "On the bluffs forming the eastern bank of the Delaware River, south of Trenton, N. J. on the site of one or more extensive Indian towns, fractions of these stones in great numbers have been found, a few are only blocked out." Here we also have a great waterway area. You will note in the preceding paragraphs the states mentioned and the great number of these objects produced. It is pertinent to the canoe-prow theory that these are lake states and abound in waterways. The primitive inhabitants were for the most part of Iroquoian and Algonkian stocks, both of which groups used canoes. The area is also the center of the thunderstorm section. What more logical supposition could be advanced than that the people living in this area, bound by certain religious beliefs and seeking constantly to placate the spirits causing the storms-the thunder birds, and at the same time desiring to protect their lives and property, would attach to their canoes an image of the thunder bird as they presumed it to be? 'The reactions of primitive minds to natural phenomena are in the majority of cases identical, irrespective of racial characteristics or geographical separation. The Solomon Islanders follow a similar practice for the protection of their canoes. Instead of the thunder-bird, the frigate bird is used and endowed with certain human characteristics. The frigate bird, no doubt, was selected for its almost supernatural ability to rest upon the water irrespective of storm or calm.

The canoe-prow theory would account for the rarity of birdstones in the burials of these peoples, including the mound builders. First, the Iroquoian people, if accepted (as they are by many students) as those who drove from the mound district the builders of the mounds, most naturally would not have left a product of theirs within the mounds. Second, had the birdstone been an article of personal adornment, or a warfare or hunting fetish, it would be found in the graves of those who made it. But if attached to a canoe, it would be lost when the canoe was lost or, if preserved, transferred to another bark. The holes in the base of the object would simplify attachment to the canoe, while freedom from excessive wear in the holes, showing that they were firmly attached, as well as their unmutilated condition, except as caused by the finder, would further tend to strengthen the canoe-prow theory. Additional substantiation is found in the almost total absence of these objects at sites of plains or desert inhabitants.

Birds shaped of wood, in no respect akin to the birdstones, have been noted 
attached to the grave posts of certain Algonkin tribes. This may be a further development of the thunder-bird idea.

Isolated cases have been noted of the finding of birdstones in the stonegrave burials of Tennessee, although the rarity of their occurrence would not make this an important factor in the canoe-prow theory.

RALPH H. Whitehead

Boston, Pennsylvania

\section{Stoppers or Modeling Tools}

In an article entitled Various Implements of Earthen Ware, Bureau of American Ethnology Annual Report 20, pages 35-36, illustration and mention are made of what the writer calls "trowel like objects of baked clay which are occasionally found in the central districts of the Mississippi valley."

He further states, "When placed stem downward these implements very closely resemble an ordinary form of toadstool. They have been regarded by some as stoppers for bottles but this was certainly not their normal use, and General Thruston is probably right in classing them as modeling tools for pottery making."

In my collection I have a pottery water bottle which was found with a stopper in place, shaped like a toadstool. These specimens were found at BoneBank, an ancient village site situated on the banks of the Wabash River, Posey County, Indiana.

I have heard questioned the opinion of General Thruston that these toadstool-shaped objects were not normally used as stoppers for bottles, and I should like to hear the opinion of some interested students.

Thomas J. Dillingham

Boonville, Indiana

\section{“Cell-Tempered" Pottery}

In American Antiquity, Vol. 1, No. 2, pp. 152-153, the Editor quotes a report on "cell-tempered" pottery by J. O. Everhart. Dr. Everhart points out the facts that calcite can be positively identified optically by refractive indices, that it is subject to solution by acidulated ground waters, and that the shape of the cavities in the pottery is such as would be formed by shell fragments but not by any of the other forms in which calcite occurs. As long as some material remains in the cavities it should, therefore, be a simple matter to prove whether or not the "cell-tempered" pastes are in reality only shell-tempered pastes which have been subject to leaching.

Dr. Everhart's suggestion regarding the original mineralogical composition of the shell, and his explanation of the spalling of the sherds call, however, for demonstration. The statement that "Most marine shells are composed largely of aragonite-" is insufficient basis for supposing that these particular shells 